\title{
Genetic Parameter Estimates in Yellow Passion Fruit Based on Design I
}

\author{
Gustavo Menezes Gonçalves ${ }^{1 *}$, Alexandre Pio Viana ${ }^{1}$, Messias Gonzaga Pereira ${ }^{1}$, Francisco \\ Valdevino Bezerra Neto ${ }^{1}$, Antônio Teixeira do Amaral Júnior ${ }^{1}$, Telma Nair Santana \\ Pereira $^{1}$ and Tiago José Menezes Gonçalves ${ }^{2}$ \\ ${ }^{1}$ Laboratório de Melhoramento Genético Vegetal; Universidade Estadual do Norte Fluminense; Av. Alberto \\ Lamego, 2000; 28015-620; Campos dos Goytacazes - RJ - Brasil. ${ }^{2}$ Centro de Ciência e Tecnologia; Universidade \\ Estadual do Norte Fluminense; Av. Alberto Lamego, 2000; 28015-620; Campos dos Goytacazes - RJ - Brasil
}

\begin{abstract}
The aim of this work was to study the genetic parameters, to obtaine the progenies by crossings among the yellow passion fruits cultivars (Passiflora edulis f. flavicarpa), following the Design I. The results of the variance analysis demonstrated large variability to be exploited in the population. The trait number of fruit per plant presented the largest additive genetic variation coefficient, demonstrating that larger gains could be obtained for the trait. In terms of genetic action, number of fruits per plant, skin thickness and number of days by flowering have demonstrated to be characterized by the overdominance. Other important traits seem to have presented larger addictive effect than the dominance, as weight, length and width of fruits. The highest values of the coefficients of heritabilities were obtained for the males and the smallest for the females within males, and for the selection the coefficients should be used in the narrow sense.
\end{abstract}

Key words: Genetic gain, genetic components, nested design, Passiflora.

\section{INTRODUCTION}

Brazil is a large producer of yellow passion fruit with an increasing demand to the processed juice and "in natura" fruit markets. The main limiting factors in yellow passion fruit is the low yield caused by factors that include the lack of high yielding genotypes and the large variability of commercial orchards, which suggest the need for crop genetic improvement.

The improvement of yellow passion fruit is directly related to the fruit, which focus on three main points: improvement aiming to satisfy the market exigencies (quality), increase of productivity and resistance to diseases.
As the yellow passion fruit is an allogamous plant, it is possible to apply several methods of improvement, either by increasing the frequency of favorable genes or by exploitation of the hybrid vigor (Bruckner, 1997). The frequency of favorable genes can be increased through either mass selection or selection with progeny test, whereas the hybrid vigor is exploited through the hybrids, synthetic varieties or compounds (Albuquerque, 2001).

Genetic parameter estimation is an important step for increasing the breeding program efficiency. Elucidation of gene action involved in the control of the quantitative traits allows the assessment of the efficiency of the different breeding strategies

\footnotetext{
*Author for correspondence: gustavog@uenf.br
} 
by obtaining predicted genetic gains and preserving a suitable genetic base. The most important genetic parameters are the additive and non-additive genetic variance components, hereditability and correlations (Cruz and Carneiro, 2003).

According to Falconer (1987), additive genetic variance is the main cause of similarity among relatives. It is the main determinant of the genetic properties of a population and of the population response to selection.

Hanson (1963) stated that heritability could be defined as the fraction of the selection differential that could be used in a selection. It could be used in the broad or narrow sense.

Design I (Comstock and Robinson, 1948) has been used to estimate the components of genetic variance of a population (Hallauer and Miranda Filho, 1988; Cruz and Carneiro, 2003). The families in this design, frequently used in corn breeding (Hallauer and Miranda Filho, 1988; Eyerabide and Hallauer, 1991; Furtado, 1996) allow the adoption of different selection strategies, such as selection among the males, among females, among females within males and combined selection, when the assessment is made at plot mean or plot total levels. The plots are formed by a group of individuals that are samples of the descendents of a cross (Cruz and Carneiro, 2003).

The present study was carried out to estimate the genetic parameters of yield in a yellow passion fruit population.

\section{MATERIAL AND METHODS}

Plants sampled from 113 progenies derived from the crosses following the Design I of Comstock and Robinson (1948) were assessed in a commercial farming area in Campos dos Goytacazes, RJ from May to July 2002. This population consisted of the following materials of yellow passion fruit (Passiflora edulis $f$. flavicarpa): Maguary, Yellow Master and selections of São Francisco do Itabapoana, with inbreeding coefficient of $\mathrm{F}=0$. For this, male donor plant was crossed with a group of five receptor plants (female) to obtain full sib and half sib progenies. The experiments were performed in Viçosa, MG (20 $45^{\prime} \mathrm{S}$ and $42^{\circ} 53 \mathrm{~W}$, altitude $648 \mathrm{~m}$, annual average temperature of $19.4^{\circ} \mathrm{C}$ ) and Miracema, RJ $\left(21^{\circ} 25^{\prime} \mathrm{S}\right.$ and $42^{\circ} 12^{\prime} \mathrm{W}$, altitude $137 \mathrm{~m}$, annual average temperature of $23^{\circ} \mathrm{C}$ ), in November 2002.

The final assessment was made in May 2004. A randomized complete block design with three replications and with each plot consisting of three plants was used. The progenies (treatments) were grouped into three sets: set 1 - progenies from 01 to 40 ; set 2 - progenies from 41 to 80 and set 3 progenies from 81 to 113 . Each set formed one treatment group.

The following plant traits were analyzed: a) number of fruit per plant - assessed by counting the number of fruit from the first flowering in each plot and dividing the result by the number of plants; b) fruit weight - the mean value obtained, in grams, by weighing samples of 25 fruits per plot; c) fruit length - mean value obtained in mm, by measuring the longitudinal dimension in samples of 25 fruits per plot; d) fruit width - mean value obtained in $\mathrm{mm}$, by measuring the transversal dimension in samples of 25 fruits per plot; e) skin thickness - mean value obtained, in $\mathrm{mm}$, by measuring the dimension of the skin in the mid-portion of the fruit (cut transversally) in samples of 25 fruits per plot; f) number of days to flowering - obtained by counting the number of days from planting in the field to the opening of the first flower in the plot; g) pulp percentage mean value obtained, expressed as percentage of the fruit, by weighing the pulp (seeds, aril and juice) in samples of 25 fruits per plot.

The genetic statistical model shown in Table 1 (Furtado, 1996; Cruz and Carneiro, 2003) was used for the analyses of variance for each trait in individual environments. The model shown in Table 2 (Hallauer and Miranda Filho, 1988; Pereira and Amaral Júnior, 2001) was used for the joint analysis over the environments.

The number of the females within males in the experiments was equal except within the last male. In the estimates carried out by mean squares, the number of females " $\mathrm{f}$ " was corrected as recommended by Barbin (1993) and Cruz and Carneiro (2003). 
Table 1 - Statistical genetic models with their expected mean squares estimates and the F test used in the individual analysis.

\begin{tabular}{cclll}
\hline $\mathbf{S V}^{\mathbf{1}}$ & $\mathbf{D F}$ & $\mathbf{M S}$ & $\mathbf{E}(\mathbf{M S})$ & $\mathbf{F}$ \\
\hline $\mathrm{S}$ & $\mathrm{s}-1$ & & \\
$\mathrm{R} / \mathrm{S}$ & $\mathrm{s}(\mathrm{r}-1)$ & & & \\
{$[\mathrm{P}]$} & {$[\mathrm{s}(\mathrm{mf}-1)]$} & $\mathrm{MS}_{4}$ & $\sigma^{2}+\mathrm{r}_{\mathrm{P}}^{2}$ & $\mathrm{MS}_{4} / \mathrm{MS}_{1}$ \\
$\mathrm{M} / \mathrm{S}$ & $\mathrm{s}(\mathrm{m}-1)$ & $\mathrm{MS}_{3}$ & $\sigma^{2}+\mathrm{r}_{\mathrm{F}}^{2}+\mathrm{rf \sigma}_{\mathrm{M}}^{2}$ & $\mathrm{MS}_{3} / \mathrm{MS}_{2}$ \\
$\mathrm{~F} / \mathrm{M} / \mathrm{S}$ & $\mathrm{sm}(\mathrm{f}-1)$ & $\mathrm{MS}_{2}$ & $\sigma^{2}+\mathrm{r \sigma}_{\mathrm{F}}^{2}$ & $\mathrm{MS}_{2} / \mathrm{MS}_{1}$ \\
$\mathrm{E}$ & $\mathrm{s}(\mathrm{r}-1)(\mathrm{mf}-1)$ & $\mathrm{MS}_{1}$ & $\sigma^{2}$ & \\
\hline $\mathrm{T}$ & $\mathrm{smfr}-1$ & &
\end{tabular}

Table 2 - Statistical genetic models with their expected mean squares estimates and the F test used in the joint analysis.

\begin{tabular}{|c|c|c|c|c|}
\hline $\mathbf{S V}^{1 /}$ & DF & MS & $\mathbf{E}(\mathbf{M S})^{2 /}$ & $\mathbf{F}$ \\
\hline $\mathrm{E}$ & e-1 & $\mathrm{MS}_{10}$ & $\sigma^{2}+\mathrm{r} \theta \sigma_{\mathrm{EF}}^{2}+\operatorname{rf} \theta \sigma_{\mathrm{EM}}^{2}+\mathrm{fm} \sigma_{\mathrm{R}}^{2}+\mathrm{fmr} \theta \sigma_{\mathrm{ES}}^{2}+\mathrm{fmrs} \Phi_{\mathrm{E}}$ & \\
\hline $\mathrm{S}$ & s-1 & $\mathrm{MS}_{9}$ & $\sigma^{2}+\operatorname{re} \sigma_{F}^{2}+\operatorname{ref} \sigma_{M}^{2}+r e f m \sigma_{S}^{2}$ & \\
\hline ExS & $(\mathrm{e}-1)(\mathrm{s}-1)$ & $\mathrm{MS}_{8}$ & $\sigma^{2}+\mathrm{r} \theta \sigma_{\mathrm{EF}}^{2}+\mathrm{rf} \theta \sigma_{\mathrm{EM}}^{2}+\mathrm{fm} \sigma_{\mathrm{R}}^{2}+\mathrm{fmr} \theta \sigma_{\mathrm{ES}}^{2}$ & \\
\hline $\mathrm{R} / \mathrm{ExS}$ & es $(r-1)$ & $\mathrm{MS}_{7}$ & $\sigma^{2}+\mathrm{fm} \sigma_{R}^{2}$ & \\
\hline$[\mathrm{P}]$ & {$[\mathrm{s}(\mathrm{mf}-1)]$} & $\mathrm{MS}_{6}$ & $\sigma^{2}+\operatorname{re} \sigma_{P}^{2}$ & $\mathrm{MS}_{6} / \mathrm{MS}_{1}$ \\
\hline $\mathrm{M} / \mathrm{S}$ & $\mathrm{s}(\mathrm{m}-1)$ & $\mathrm{MS}_{5}$ & $\sigma^{2}+\operatorname{re} \sigma_{F}^{2}+\operatorname{ref} \sigma_{M}^{2}$ & $\mathrm{MS}_{5} / \mathrm{MS}_{4}$ \\
\hline $\mathrm{F} / \mathrm{M} / \mathrm{S}$ & $m s(f-1)$ & $\mathrm{MS}_{4}$ & $\sigma^{2}+r e \sigma_{F}^{2}$ & $\mathrm{MS}_{4} / \mathrm{MS}_{1}$ \\
\hline ExM/S & $\mathrm{s}(\mathrm{e}-1)(\mathrm{m}-1)$ & $\mathrm{MS}_{3}$ & $\sigma^{2}+r \theta \sigma_{E F}^{2}+\operatorname{rf} \theta \sigma_{E M}^{2}$ & $\mathrm{MS}_{3} / \mathrm{MS}_{2}$ \\
\hline $\mathrm{ExF} / \mathrm{M} / \mathrm{S}$ & $\mathrm{ms}(\mathrm{e}-1)(\mathrm{f}-1)$ & $\mathrm{MS}_{2}$ & $\sigma^{2}+r \theta \sigma_{E F}^{2}$ & $\mathrm{MS}_{2} / \mathrm{MS}_{1}$ \\
\hline $\mathrm{E}$ & es(r-1)(fm-1) & $\mathrm{MS}_{1}$ & $\sigma^{2}$ & \\
\hline $\mathrm{T}$ & emrsf-1 & & & \\
\hline
\end{tabular}

The mean squares values obtained in the joint analysis of variance of the data from Viçosa and Miracema were used to estimate the components of variance associated to the genetic effects of the statistical model, which are male effect $\left(\hat{\sigma}_{M}^{2}\right)$ and female within male effect ( $\hat{\sigma}_{\mathrm{F}}^{2}$ ), by:

$\hat{\sigma}_{\mathrm{M}}^{2}=\frac{\mathrm{MS}_{5}-\mathrm{MS}_{4}}{\text { ref }}$ and $\hat{\sigma}_{\mathrm{F}}^{2}=\frac{\mathrm{MS}_{4}-\mathrm{MS}_{1}}{\mathrm{re}}$

The description of these components was obtained from the knowledge of the covariance among the related individuals assessed in Design I (full sibs -
FS and half sibs - HS) according to Furtado (1996) and Cruz and Carneiro (2003), given by:

$$
\operatorname{COV}(\mathrm{FS})=\sigma_{\mathrm{M}}^{2}+\sigma_{\mathrm{F}}^{2} \text { and } \operatorname{COV}(\mathrm{HS})=\sigma_{\mathrm{M}}^{2}
$$

By the principle of resemblance among relatives, the covariances between FS and HS can be expressed in terms of additive genetic variance $\left(\hat{\sigma}_{\mathrm{A}}^{2}\right)$ and dominance genetic variance $\left(\hat{\sigma}_{\mathrm{D}}^{2}\right)$. According to Falconer (1987) and Cruz and Carneiro (2003), in a non-inbred population $(\mathrm{F}=0)$ and in the absence of epistasis: 
$\operatorname{COV}(\mathrm{FS})=\frac{1}{2} \sigma_{\mathrm{A}}^{2}+\frac{1}{4} \sigma_{\mathrm{D}}^{2}$ and $\operatorname{COV}(\mathrm{HS})=\frac{1}{4} \sigma_{\mathrm{A}}^{2}$

The covariances among relatives can be equated with the components of genetic variance:

$\hat{\sigma}_{\mathrm{A}}^{2}=4 \hat{\sigma}_{\mathrm{M}}^{2}$ and $\hat{\sigma}_{\mathrm{D}}^{2}=4\left(\hat{\sigma}_{\mathrm{F}}^{2}-\hat{\sigma}_{\mathrm{M}}^{2}\right)$

Similarly, additive genetic variance $\mathrm{x}$ environment interaction and dominance genetic variance $\mathrm{x}$ environment interaction are expressed by:

$\hat{\sigma}_{\mathrm{AE}}^{2}=4 \hat{\sigma}_{\mathrm{EM}}^{2}$ and $\hat{\sigma}_{\mathrm{DE}}^{2}=4\left(\hat{\sigma}_{\mathrm{EF}}^{2}-\hat{\sigma}_{\mathrm{EM}}^{2}\right)$

The following parameters can be estimated:

a) Average degree of dominance: $\mathrm{ADD}=\sqrt{2 \hat{\sigma}_{\mathrm{D}}^{2} / \hat{\sigma}_{\mathrm{A}}^{2}}$

b) Additive genetic variance coefficient: $C \hat{V}_{\mathrm{a}}=\left(100 \sqrt{\hat{\sigma}_{\mathrm{A}}^{2}}\right) / \hat{\mathrm{m}}$

c) Experimental coefficient of variation: $\mathrm{CV}_{\mathrm{e}}=\left(100 \sqrt{\mathrm{QM}_{1}}\right) / \hat{\mathrm{m}}$

The broad and narrow senses heritabilities, at the plot mean level, for the joint analysis over environments were estimated for each one of the possible selection alternatives derived from Design I, as described by Furtado (1996) and Cruz and Carneiro (2003):

a) Broad and narrow sense heritabilities for selection based on the male means: selection is carried out between male family means. The heritabilities in the broad $\left(\mathrm{h}_{\mathrm{MB}}^{2}\right)$ and the narrow sense $\left(\mathrm{h}_{\mathrm{MN}}^{2}\right)$ are given by:

$\mathrm{h}_{\mathrm{MB}}^{2}=\frac{\hat{\sigma}_{\mathrm{M}}^{2}+\frac{\hat{\sigma}_{\mathrm{F}}^{2}}{\mathrm{f}}}{\frac{\mathrm{MS_{5 }}}{\text { ref }}}$ and $\mathrm{h}_{\mathrm{MN}}^{2}=\frac{\frac{\mathrm{f}+1}{4 \mathrm{f}} \hat{\sigma}_{\mathrm{A}}^{2}}{\frac{\mathrm{MS} S_{5}}{\text { ref }}}$

b) Broad and narrow sense heritabilities for selection based on the female means: selection was carried out among the female families means, regardless of the male to which they belong. The heritability in the broad $\left(\mathrm{h}_{\mathrm{FB}}^{2}\right)$ and narrow sense $\left(\mathrm{h}_{\mathrm{FN}}^{2}\right)$ are given by:

$\mathrm{h}_{\mathrm{FB}}^{2}=\frac{\frac{\mathrm{f}(\mathrm{m}-1)}{\mathrm{mf}-1} \hat{\sigma}_{\mathrm{M}}^{2}+\hat{\sigma}_{\mathrm{F}}^{2}}{\frac{\mathrm{MS}_{6}}{\mathrm{re}}}$

and
$\mathrm{h}_{\mathrm{FN}}^{2}=\frac{\frac{2 \mathrm{mf}-\mathrm{f}-1}{\mathrm{mf}-1} \times \frac{1}{4} \hat{\sigma}_{\mathrm{A}}^{2}}{\frac{\mathrm{MS}_{6}}{\mathrm{re}}}$

c) Broad and narrow sense heritabilities for selection based on the female within male means: stratified selection was carried out on families of females, where a number of families of each group of females was selected within each male. The heritabilities in the broad $\left(\mathrm{h}_{\mathrm{F} / \mathrm{MB}}^{2}\right)$ and narrow senses $\left(\mathrm{h}_{\mathrm{F} / \mathrm{MN}}^{2}\right)$ are given by:

$\mathrm{h}_{\mathrm{F} / \mathrm{MB}}^{2}=\frac{\frac{1}{4} \hat{\sigma}_{\mathrm{A}}^{2}+\frac{1}{4} \hat{\sigma}_{\mathrm{D}}^{2}}{\frac{\mathrm{MS}_{4}}{\mathrm{re}}}$ and $\mathrm{h}_{\mathrm{F} / \mathrm{MN}}^{2}=\frac{\frac{1}{4} \hat{\sigma}_{\mathrm{A}}^{2}}{\frac{\mathrm{MS}_{4}}{\mathrm{re}}}$

\section{RESULTS AND DISCUSSION}

The results of the individual analysis of variance (Table 3) showed significant differences among the treatments (progenies) by the $\mathrm{F}$ test $(\mathrm{P}<0.05)$ for most studied traits, except pulp percentage in Viçosa and number of days to flowering in Miracema. The genetic variability among the progenies was evaluated as sufficient to allow a successful breeding program.

The progenies degrees of freedom were partitioned into male effects and female within the male effects, according to Design I of Comstock and Robinson (1948). These effects were significant according to the $\mathrm{F}$ test for most of the studied traits. In Viçosa, only the pulp percentage trait females within the males effect was not significant $(\mathrm{P}>0.05)$, indicating that selection would be effective only among the males for this trait. In Miracema, the number of fruits per plant and number of days to flowering were not significant for either of the effects studied, except to progenies for number of fruits. 
$\underline{\text { Table } 3 \text { - Analysis of variance of yield traits }}{ }^{2 /}$ in yellow passion fruit.

\begin{tabular}{|c|c|c|c|c|c|c|c|c|c|}
\hline \multirow{2}{*}{ Environments } & \multirow{2}{*}{$\mathrm{SV}^{1 /}$} & \multirow{2}{*}{ DF } & \multicolumn{7}{|c|}{ Mean Squares } \\
\hline & & & NF & FW & FL & FWI & ST & NDF & $\mathbf{P P}$ \\
\hline \multirow{5}{*}{ Viçosa } & {$[\mathrm{P}]$} & 110 & $457.58 * *$ & $1952.02 * *$ & $104.65 * *$ & $38.98 * *$ & $3.32 * *$ & $401.75^{* *}$ & 69.51 \\
\hline & $\mathrm{M} / \mathrm{S}$ & 20 & $768.80^{*}$ & $4718.57 * *$ & $251.89 * *$ & $87.95^{* *}$ & $6.33^{* *}$ & $867.75 * *$ & $112.02 *$ \\
\hline & $\mathrm{F} / \mathrm{M} / \mathrm{S}$ & 90 & $388.42 * *$ & $1337.23 * *$ & $71.93 * *$ & $28.10^{* *}$ & $2.66^{* *}$ & $298.19 * *$ & 60.06 \\
\hline & $\mathrm{CVe}(\%)$ & & 44.52 & 13.81 & 5.00 & 4.76 & 13.08 & 9.00 & 22.33 \\
\hline & Mean & & 22.09 & 199.99 & 86.29 & 76.68 & 7.47 & 115.19 & 45.79 \\
\hline \multirow{5}{*}{ Miracema } & {$[\mathrm{P}]$} & 110 & $306.25 *$ & $1071.21 * *$ & $65.98 * *$ & $25.56 * *$ & $1.21 * *$ & 224.90 & \\
\hline & $\mathrm{M} / \mathrm{S}$ & 20 & 421.22 & $2277.75 * *$ & $155.98 * *$ & $47.03 * *$ & $1.86^{*}$ & 255.61 & \\
\hline & $\mathrm{F} / \mathrm{M} / \mathrm{S}$ & 90 & 280.71 & $803.09 * *$ & $45.98^{* *}$ & $20.79 * *$ & $1.07 * *$ & 218.07 & \\
\hline & $\mathrm{CVe}(\%)$ & & 47.30 & 13.52 & 5.94 & 4.93 & 15.10 & 9.51 & \\
\hline & Mean & & 32.30 & 170.37 & 86.21 & 74.02 & 5.39 & 138.87 & \\
\hline \multirow{7}{*}{ joint analysis } & {$[\mathrm{P}]$} & 110 & $504.13 * *$ & $2330.71 * *$ & $139.51 * *$ & $47.53 * *$ & $3.26^{* *}$ & $408.09 * *$ & \\
\hline & $\mathrm{M} / \mathrm{S}$ & 20 & $851.08^{*}$ & $5958.12 * *$ & $362.46 * *$ & $113.18 * *$ & $6.20 * *$ & $830.44 * *$ & \\
\hline & $\mathrm{F} / \mathrm{M} / \mathrm{S}$ & 90 & $427.03 * *$ & $1524.62 * *$ & $89.96^{* *}$ & $32.94 * *$ & $2.60^{* *}$ & $314.24 * *$ & \\
\hline & ExM/S & 20 & 316.98 & 969.67 & 43.75 & 19.92 & $1.87 *$ & 279.52 & \\
\hline & $\mathrm{ExF} / \mathrm{M} / \mathrm{S}$ & 90 & $247.47 * *$ & 588.05 & 27.87 & 15.58 & $1.07 *$ & $207.68 * *$ & \\
\hline & $\mathrm{CVe}$ & & 47.13 & 13.75 & 5.48 & 4.85 & 13.98 & 9.33 & \\
\hline & Mean & & 27.11 & 185.42 & 86.25 & 75.37 & 6.45 & 126.84 & \\
\hline
\end{tabular}

The progenies effects in joint analysis were significant at the $5 \%$ level of probability ( $\mathrm{F}$ test) for all the traits. Similarly, the male effects and female within male effects were significant for all the studied traits. The genetic variance detected by the joint analysis corresponded to the mean variance in the various environments studied, subtracted from the interaction (Cruz et al., 2004). The results by comparison of average of two experiments, indicated that Miracema was more flowering inducer, probably due climatic conditions as temperature and luminosity.

Comparing the average of the two experiments, it was observed that the production in number of fruits per plant was notoriously higher in Miracema (32.30 fruits/plant) than in Viçosa (22.09 fruits/plant). However, the fruits from Viçosa had better quality - displaying highest weight, length and width; despite of presenting a little thicker skin, which was not favorable. The lack of significance for the male $\mathrm{x}$ environment interaction and female within male $\mathrm{x}$ environment interaction for fruit weight, fruit length and width, also for the male $\mathrm{x}$ environment interaction for number of fruits per plant and number of days to flowering indicated a similar performance of these traits in both the environments studied. These data suggested that superior genotypes could be recommended simultaneously for cropping in both the environments.

The genetic parameters were estimated from the joint analysis of Viçosa and Miracema since the genotype $\mathrm{x}$ interaction was no significant for most of the traits. The pulp percentage trait was excluded from the analysis since it was not assessed in Miracema and was not significant in Viçosa.

The estimates of the genetic parameters for the joint analysis (Table 4) showed better importance of the dominance variance $\left(\hat{\sigma}_{\mathrm{D}}^{2}\right)$ comparatively to 
the additive genetic variance $\left(\hat{\sigma}_{\mathrm{A}}^{2}\right)$ for the number of fruits per plant, skin thickness and number of days to flowering, indicated by the larger than the unit average degree of dominance, therefore being also more affected by the environment.

These results suggested the presence of overdominance in the control of these traits. According to Cruz and Carneiro (2003), dominance genetic variance could be seen from two points of view: a) first, positively in relation to the chances of success of obtaining heterotic hybrids; b) second, as a disturbing factor in superior genotypes selection from segregant populations, where the gains in population breeding were based on the magnitude of the additive genetic variance.

Table 4 - Genetic parameter estimates for six traits assessed in yellow passion fruit progenies by joint environmental analysis

\begin{tabular}{|c|c|c|c|c|c|c|c|c|}
\hline \multirow{2}{*}{ Traits $^{1 /}$} & \multicolumn{8}{|c|}{ Genetic parameters $^{2 /}$} \\
\hline & $\hat{\sigma}_{M}^{2}$ & $\hat{\sigma}_{\mathrm{F}}^{2}$ & $\hat{\sigma}_{\mathrm{A}}^{2}$ & $\hat{\sigma}_{\mathrm{D}}^{2}$ & $\hat{\sigma}_{\mathrm{AE}}^{2}$ & $\hat{\sigma}_{\mathrm{DE}}^{2}$ & ADD & $C \hat{\mathrm{V}}_{\mathrm{a}}(\%)$ \\
\hline $\mathrm{NF}$ & 14.39 & 43.96 & 57.56 & 118.29 & 9.43 & 46.71 & 2.03 & 27.99 \\
\hline FW & 150.45 & 145.83 & 601.78 & 0.00 & 51.80 & 0.00 & 0.00 & 13.23 \\
\hline FL & 9.25 & 11.27 & 36.99 & 8.11 & 2.16 & 1.55 & 0.66 & 7.05 \\
\hline FWI & 2.72 & 3.27 & 10.89 & 2.18 & 0.59 & 0.91 & 0.63 & 4.38 \\
\hline $\mathrm{ST}$ & 0.12 & 0.30 & 0.49 & 0.71 & 0.11 & 0.06 & 1.70 & 10.84 \\
\hline $\mathrm{NDF}$ & 17.52 & 29.03 & 70.07 & 46.05 & 9.75 & 35.32 & 1.15 & 6.60 \\
\hline
\end{tabular}

${ }^{1 /} \mathrm{NF}$ - number of fruits per plant; FW - fruit weight, in grams; FL - fruit length in mm; FWI - fruit width in mm; ST - skin thickness in mm; NDF - number of days to flowering;

${ }^{2 /} \hat{\sigma}_{\mathrm{M}}^{2}$, $\hat{\sigma}_{\mathrm{F}}^{2}=$ estimates of the components of variance associated to genetic effects: male effect and female within male effect, respectively.

$\hat{\sigma}_{\mathrm{A}}^{2}$ e $\hat{\sigma}_{\mathrm{D}}^{2}=$ estimates of the components of variance genetic between individuals: additive genetic variance and genetic variance due to deviations of dominance, respectively;

$\hat{\sigma}_{\mathrm{AE}}^{2}$ e $\hat{\sigma}_{\mathrm{DE}}^{2}=$ estimates of variances: additive genetic $\mathrm{X}$ environments and due to deviations of dominance $\mathrm{X}$ environments, respectively;

ADD e $C \hat{V}_{\mathrm{a}}=$ average degree of dominance and additive genetic variance coefficient, respectively.

The degrees of dominance (ADD) lower than one was detected for fruit weight, fruit length and width, showing that the additive component had greater importance in the expression of these traits. The high magnitude of the additive genetic variance component suggested the covariance among the progenies and their respective relatives, thus it was determinant of the gain to be obtained by the selection.

The dominance variance component $\left(\hat{\sigma}_{\mathrm{D}}^{2}\right)$ was negative for fruit weight and considered null in this study. According to Hallauer and Miranda Filho (1988), as long as different females were crossed with the same male, as in Design I, these females could receive similar pollen grains, thus the female within the male component $\left(\hat{\sigma}_{\mathrm{F}}^{2}\right)$ could be reduced in value, naturally underestimating the deviations of dominance. Further, Gouesnard and
Gallais (1992) reported that the mating system carried out in Design I tended to favor the homozygosis, thus resulting in the overestimation of the additive genetic variance at the cost of decreasing the dominance variance. The value of the female within male component can also be minimized by a higher residual mean square value, or further by low precision in the $\hat{\sigma}_{\mathrm{D}}^{2}$ estimates by Design I.

The number of fruits per plant presented the highest coefficient of additive genetic variance $\left(\hat{C V}_{\mathrm{a}}\right), 27.99 \%$, indicating that expressive gains could be obtained from the selection for this trait. Viana et al. (2004) also reached this conclusion after obtaining coefficients of genetic variation of $50.46 \%$ for Macaé, $62.18 \%$ for Campos dos Goytacazes and $52.78 \%$ for the joint analysis, 
which were higher compared to the value obtained for other traits.

Most of the other traits showed moderate $\mathrm{CV}_{\mathrm{a}}$ values, indicating that gains could also be obtained, but smaller than for number of fruits.

According to Falconer (1987), in practice, the total variance could be divided into additive genetic variance, which was interesting for the breeding programs, and the remainder, which consisted of non-additive genetic variances and the environmental variance. Therefore, the coefficient of additive genetic variance is important and expresses the additive genetic standard deviation in percentage of the mean and is an indicator of the level of gain that can be obtained by selection for a given trait.

Table 5 shows the estimates of the heritability coefficients in the broad and the narrow senses, based on the means of the male families, female families and female within the male families.

Table 5 - Broad and narrow sense heritability coefficients based on means of male families, female families and female within male families, in the joint analysis.

\begin{tabular}{|c|c|c|c|c|c|c|}
\hline \multirow{2}{*}{$\mathrm{h}^{2}(\%)^{2 /}$} & \multicolumn{6}{|c|}{ Traits $^{1 /}$} \\
\hline & NF & FW & FL & FWI & ST & NDF \\
\hline $\mathrm{h}_{\mathrm{MB}}^{2}$ & 80.82 & 89.56 & 93.94 & 88.22 & 86.90 & 83.13 \\
\hline $\mathrm{h}_{\mathrm{MN}}^{2}$ & 59.97 & 89.56 & 90.49 & 85.33 & 69.83 & 74.82 \\
\hline $\mathrm{h}_{\mathrm{FB}}^{2}$ & 68.85 & 76.11 & 86.87 & 74.42 & 76.69 & 67.53 \\
\hline $\mathrm{h}_{\mathrm{FN}}^{2}$ & 33.65 & 76.11 & 78.15 & 67.54 & 44.19 & 50.61 \\
\hline $\mathrm{h}_{\mathrm{F} / \mathrm{MB}}^{2}$ & 61.77 & 59.21 & 75.19 & 59.52 & 68.80 & 55.43 \\
\hline $\mathrm{h}_{\mathrm{F} / \mathrm{MN}}^{2}$ & 20.22 & 59.21 & 61.67 & 49.59 & 28.14 & 33.45 \\
\hline $\begin{array}{l}{ }^{1 /} \mathrm{NF}-\text { numb } \\
\mathrm{NDF}-\mathrm{nur}\end{array}$ & $\begin{array}{l}\text { its per } \mathrm{pl} \\
\text { days to flo }\end{array}$ & ruit weig & s; FL - f & in $\mathrm{mm}$; $\mathrm{F}$ & width in & thicknes \\
\hline
\end{tabular}

Generally, the highest heritability coefficients were obtained for the male families, and the lowest for the females within the male families. It should be pointed out that the estimates of high heritability could occur for the traits with small additive genetic variance, as long as the environmental influence on the trait was small. The reverse is also true. In fact, this may have occurred for the number of fruits per plant, which presented one of the lowest heritability estimates although it had the highest coefficient of additive genetic variation. The presence of a large environmental component might have caused the low heritability estimate since the experiment presented a large coefficient of variation.

Viana et al. (2004), when starting a breeding program for the North and Northeast of Rio de Janeiro state, estimated the genetic parameters for several traits in a yellow passion fruit population. The authors detected high broad heritability
$(92.10 \%)$ and variation index higher than one (2.93) for the number of fruits and high heritability for fruit length $(82.84 \%)$, which indicated a situation favorable to the improvement of these traits in a joint analysis of Campos dos Goytacazes and Macaé environments. In the same experiments, acidity and juice percentage presented the lowest heritabilities among the traits, 19.07 and $0.00 \%$, respectively.

Since narrow sense heritability refers to the fraction of the phenotypic differences among the parents that are expected to be recovered among the descendents, it may be used in a breeding program to calculate the expected progress from selection. On the other hand, broad sense heritability considers the total genetic variability, which is only partially transmitted to the descendents. 


\section{RESUMO}

Com o objetivo de se estimarem parâmetros genéticos, procedeu-se a obtenção de progênies por cruzamentos entre cultivares de maracujá amarelo (Passiflora edulis $f$. flavicarpa) seguindo o Delineamento I. Os resultados da análise de variância demonstraram existir grande variabilidade a ser explorada na população. Número médio de frutos expressou o maior coeficiente de variação genético aditivo, demonstrando que maiores ganhos podem ser obtidos para o caráter. Em termos de ação gênica, número de frutos por planta, espessura de casca e número de dias para o florescimento demonstraram ser caracterizadas por efeito sobredominante dos genes. Outras características importantes apresentaram efeito aditivo maior do que o dominante, como ocorreu com peso, comprimento e largura de frutos. Os valores dos coeficientes de herdabilidade mais elevados foram obtidos para famílias de machos e os menores para famílias de fêmeas dentro de machos, sendo que para fins de seleção devem ser utilizados os coeficientes no sentido restrito.

\section{REFERENCES}

Albuquerque, A. S. (2001), Seleção de genitores e híbridos em maracujazeiro (Passiflora edulis Sims). DSc. Thesis, (Genética e melhoramento de plantas), UFV, Viçosa.

Barbin, D. (1993), Componentes de variância: teoria e aplicações, 2 ed. Piracicaba: FEALQ.

Bruckner, C. H. (1997), Perspectivas do Melhoramento do Maracujazeiro. In: Manica, I. (ed.) Maracujá: temas selecionados, Porto Alegre: Cinco Continentes, p. 25-46.
Comstock, R. E.; Robinson, H. F. (1948), The components of genetic variance in populations of biparental progenies and their use in estimating the average degree of dominance. Biometrics, 4, 254-266.

Cruz, C. D.; Regazzi, A. J.; Carneiro, P. C. S. (2004), Modelos biométricos aplicados ao melhoramento genético. 3ed, v.1, Viçosa: UFV.

Cruz, C. D.; Carneiro, P. C. S. (2003), Modelos biométricos aplicados ao melhoramento genético. v2, UFV, Viçosa.

Eyherabide, G. H.; Hallauer, A. R. (1991), Reciprocal full-sib recurrent selection in maize: direct and indirect responses. Crop Science, 31, 952-959.

Falconer, D. S.; Mackay, T. F. (1996), Introduction to quantitative genetics. Longman Group, England.

Furtado, M. R. (1996), Alternativas de seleção no delineamento I de Comstock e Robinson, em milho. DSc. Thesis, (Genética e melhoramento de plantas), UFV, Viçosa.

Gouesnard, B; Gallais, A. (1992), Genetic variance component estimation in a nested mating design with positive assortative mating, and application to maize. Crop Science, 32, 1127-1131.

Hallauer, A. R.; Miranda Filho, J. B. (1988), Quantitative genetics in maize breeding. 2ed, Iowa State University Press, Ames.

Hanson, W. D. (1963), Heritability. In: Hanson, W. D.; Robinson, H. F. (eds.) Statistical genetics and plant breeding. National Academy of Science - National Research Council, Washington, pp.125-139

IBGE, 2005. http://www.sidra.ibge.gov.br in 03/02/2005.

Pereira, M. G.; Amaral Júnior, A. T. (2001), Estimation of genetic components in popcorn based on the nested design. Crop Breeding and Applied Biotechnology, 1: (1), 3-10.

Viana, A. P.; Pereira, T. N. S.; Amaral Júnior, A. T.; Souza, M. M. de; Maldonado, J. F. M. (2004), Parâmetros genéticos em populações de maracujazeiro amarelo. Revista Ceres, 51: (297), 545-555. 